\title{
MEGJEGYZÉSEK AZ ARA PACIS TELLUS-PANELJE KÖZPONTI ALAKJÁNAK AZONOSÍTÁSÁHOZ
}

Az ókori római művészettörténet egyik leggyakrabban vizsgált műalkotása az Ara Pacis Augustae. Az avatatlan szem egy kiválóan formált, részletes, domborművek sokaságát felvonultató, páratlan műalkotást lát, azonban a történettudomány és a különböző társtudományok ezen apró részletekből az Augustus-kor kiváló lenyomatát tudják nyújtani. Az Ara Pacis reliefjeinek részletgazdagsága miatt mind a római politikatörténet, mind a vallás- és eszmetörténet kutatásának kiváló forrása. Jelen tanulmány elsődleges célja állást foglalni az ikonográfiai sajátosságok és a szakirodalom segítségével abban a kérdésben, hogy ki a panel főalakja.

Kulcsszavak: Ara Pacis Augustae, Ceres, római vallás, Augustus, Tellus

\section{Az Ara Pacis Tellus-paneljének központi alakja}

Az elmúlt évtizedekben komoly vitát váltott ki az Ara Pacison található úgynevezett Tellus-panel. A vita központi kérdését a relief közepén látható alak azonosítása jelentette. A szakirodalom ennek megválaszolására többféle megoldást kínált: Tellus, Ceres, Venus vagy az isteni attribútumokkal felruházott Livia alakja. ${ }^{1}$ A kutatás mai állása szerint azonban poliszemantikus ábrázolásról beszélhetünk, amelyben több deitás sajátosságait és isteni jelvényeit használták fel.

Az alábbi tanulmány célja, hogy az Ara Pacis Tellus-paneljének ikonográfiai sajátosságait megvizsgálja, és szépirodalmi művekkel, képzőművészeti alkotásokkal, numizmatikai és régészeti leletekkel összevetve bizonyítsa, hogy a poliszemantikus felfogással szemben is érdemes érvelni amellett, hogy a relief központjában szereplő alak elsősorban Ceres istennő.

A római művészetben Ceres ikonográfiáját nagyrészt a görög Démétértől kölcsönözték. ${ }^{2}$ Farnell a következőképpen írta le a Démétér-típust: „Az istennőt általában fá-

1 A panel főalakját számos szakember Tellusként azonosítja, többek között T. Hölscher: Staatsdenkmal und Publikum. Vom Untergang der Republik bis zur Festigung des Kaisertums in Rom. Xenia 9 (1984) 87 sk., ehhez kapcsolódik E. Simon: Augustus: Kunst und Leben in Rom um die Zeitenwende. München 1986. 36 sk. Venus alakját véli fölfedezni G. K. Galinsky: Venus, Polysemy, and the Ara Pacis Augustae. AJA 96 (1992) 223-243 és A. Booth: Venus on the Ara Pacis. Latomus 25 (1966) 873-879. L. Berczelly: Ilia and the Divine Twins. ActaAArtHist 5 (1985) 89-149 úgy gondolja, hogy a gyermekeket tartó nőalak Rhea Silvia, azonban elmélete nem kapott szélesebb körű támogatást. Vö. N. De Grummond: Pax and the Horae on the Ara Pacis Augustae. AJA 94 (1990) 663-677, aki szerint a központi alakot Paxként, a béke istennőjeként is azonosíthatjuk. Ezt támogatja A. E. Cooley: Pompeii and Herculaneum. Abingdon 2003. 232 sk. Napjainkban az egyik leginkább elfogadott nézet, hogy az ábrázolás poliszemantikus. Ezt elsőként $P$. Zanker: Eine Kunst für die Sinne. Zur Bildwelt des Dionysos und der Aphrodite. Berlin 1998. 172-179 közli, majd őt követi D. Kleiner: Roman Sculpture. New Haven - London. 96 sk., valamint B. S. Spaeth: The Roman Goddess Ceres. Austin 1996. $130 \mathrm{sk}$.

2 S. De Angeli: Ceres. LIMC 4 (1988) 893-908. 
tyollal a fején, érett nőként ábrázolták, igazodva anyai funkciójához, az arc pedig markáns, az érzelmekkel és a tapasztalat lenyomatával jellemezhető." ${ }^{3} \mathrm{Ez}$ a jellemzés nagyon hasonlít az Ara Pacis központi alakjára, akárcsak irodalmi forrásokban megjelenő ábrázolásai. Az istennő irodalmi képe lényegében változatlan maradt az ókor folyamán:4 gyakran nevezik királynőnek, és általában trónon ülő, koronát viselő alakként ábrázolják. Ünnepélyesnek írják le, akit bánat és harag jellemez lányának elvesztése miatt, s általában fátylat visel gyászának jeleként. Feszesen összekötve ábrázolják haját, amely olyan szőke, mint a gabona, amelyet ő ajándékozott az emberiségnek. Démétér általános leírása tehát jellegzetességeire, isteni hatáskörére utal: korona, trón, fátyol, gabona, gyümölcsök. Az Ara Pacis reliefjének központi alakja mindezekkel rendelkezik: attribútumai általában a termékenységhez, a mezőgazdasághoz és a pásztori tevékenységekhez kötődnek.

Az Ara Pacis alakjának koronája búzaszálakból és mákgubókból áll. A corona spicea az alakot egyértelműen Ceres istennővel azonosítja, hiszen annak elsődleges attribútumai közé tartozik. ${ }^{5}$ A corona mind a görög, mind a római éremtípusokon megjelenik. ${ }^{6}$ A görög típuson gyakran kerül ábrázolásra a Persephoné-mítosz, amely közvetlenül azonosítja az istennőt, azonban ez soha nem jelenik meg a római típuson, ami a szakirodalom szerint azt sugallja, hogy római környezetben a corona önmagában is elegendő volt Ceres azonosításához. ${ }^{7}$ Emellett a corona gyakran előfordul az istennő fején más ábrázolásokon is, például a gemmákon és a szobrokon, ahogyan a latin irodalomban is általában corona spiceával jelenik meg. Az oltár ábrázolásán a corona búzaszálai és mákgubói kiemelkednek az alak jobb oldalán sarjadó növények csoportjából. ${ }^{8}$

A búzaszálak között megjelenő mákgubók önmagukban is értelmezhetők Démétér és Ceres istennőkre történő utalásként. Úgy tűnik, a mák a legkorábbi idők óta kapcsolatban állt az istennő alakjával. Egy mykénéi istenség, aki kezében mákot tart vagy mákgubós coronát visel, Démétérrel azonosítható. ${ }^{9}$ Theokritos szintén úgy írja le Démétér szobrát, hogy az kezében mákot és búzaszálakat tart. ${ }^{10} \mathrm{Ez}$ az ábrázolás tovább él a római korszakban is, Vergilius a Georgicában ceresi mákról beszél. ${ }^{11}$ Az Ara Pacis reliefjén lévő mákgubók papaver somniferumként értelmezhetők, amely különöskép-

${ }^{3}$ L. Farnell: The Cults of the Greek States. Oxford 1896-1909. 272 sk.

${ }^{4}$ L. Beschi: Demeter. LIMC 4 (1988) 846 sk.

5 Spaeth: i. m. (1. jegyz.) 34-41.

${ }^{6}$ Beschi: i. m. (4. jegyz.) 186-188.

7 Beschi: i. m. (4. jegyz.) 188.

${ }^{8}$ A. Brumfield: The Attic Festivals of Demeter and Their Relation to the Agricultural Year. New York 1981. 20-23. Démétér és a búza kapcsolatáról lásd bővebben: P. Wolters: Gestalt und Sinn der Ähre in der antiker Kunst. Die Antike 6 (1931) 284-301 és F. Muthmann: Der Granatapfel: Symbol des Lebens in der alten Welt. Bern 1982. 68 sk.

${ }_{9}$ Beschi: i. m. (4. jegyz.) 2. és 4. kép

10 Theocr. 7. 157.

11 Verg. geor. I, 212: Cereale papaver. 
pen kapcsolódik Démétér alakjához, ${ }^{12}$ ábrázolásain gyakran tart egyik kezében búzát és mákgubókat. ${ }^{13}$ Mindkét növény szimbolikusnak tekinthető, a gubó számtalan magja a termékenységet szimbolizálja, s ugyanez igaz a búzakalászra is. ${ }^{14}$ Ugyanakkor a mák és az abból kinyert ópium az alvással és a halállal is kapcsolatba hozható, és így több imitációs aspektusra is utalhat. ${ }^{15}$

A panel ugyanezen növénycsoportjában megjelenő egyéb virágok is kapcsolódhatnak az istennőhöz, bár azonosításuk bizonytalan. A központi virág máknak tünik. ${ }^{16}$ Az ettől balra látható egyik virág egy íriszfajta lehet, a másik nárcisz. ${ }^{17} \mathrm{Ha}$ azonosításuk helyes, a relief szempontjából problémát jelenthet, hogy a reprezentált virágok általában nem virágoztak egyszerre. ${ }^{18}$ Így feltételezhetően ezen növények a megjelenített képen egyszerű díszítő motívumok. A növények azonban utalhatnak arra is, milyen virágokat gyüjtött Persephoné/Proserpina, amikor Hádés/Pluto elrabolta őt Henna mezejéről, ahol egész évben virágoztak a növények. ${ }^{19} \mathrm{~A}$ nárcisz különös jelentőséggel bír Démétér és Persephoné esetében. ${ }^{20} \mathrm{~A}$ homérosi Démétér-himnuszban Persephoné éppen nárciszt szedett, amikor megnyílt a föld, és Hádés elrabolta őt. ${ }^{21}$ Bármit is ábrázolnak azonban a reliefen látható virágok, a virágzó növények általában is fontos szerepet játszottak Démétér kultuszában számos helyen, beleértve Eleusist, Hippóniumot és Sardist. ${ }^{22}$ Pausanias szerint Démétért és Persephonét isteni társaikkal, Artemisszel és Athénával együtt fejükön virágkosárral ábrázolták Eleusisban. ${ }^{23}$

Az Ara Pacis figurájának másik jellegzetessége a sziklás trón, amelyen helyet foglal. A hieratikusan ülő istennő a Démétér/Ceres-ábrázolások egyik leggyakoribb típusa. Pausanias szerint Démétér legősibb szobrai az ülő istennőt ábrázolták. ${ }^{24} \mathrm{~A}$ trón egy kisté, amely egy kör alakú kosárforma, egy szikla vagy maga a föld. ${ }^{25}$ A sziklás trónt néha az Agelastos Petrával azonosítják, amelyen az istennő ült, amikor lánya elrablását

12 G. Mylonas: Eleusis and the Eleusinian Mysteries. Princetown 1961. 52 sk. A papaver somniferum azonosítását lásd A. Seeberg: Poppies, not Pomegranates. Oslo 1969. 9 sk.

${ }^{13}$ Kitűnően példázza ezt De Angeli munkája, amelyben számos ábrázolást vizsgál meg. De Angeli: i. m. (2. jegyz.) 52-55.

${ }^{14}$ Ceres és a mák szimbolikus kapcsolatáról lásd K. Lembach: Die Pflanzen bei Theocrit. Heidelberg 1970. $162 \mathrm{sk}$.

15 Ceres és a halál különböző aspektusairól lásd Spaeth: i. m. (1. jegyz.) 53-55.

16 Démétér és a mák kapcsolatáról lásd Németh Gy.: Az álomhozó mák. Ókor 17 (2018) 60 sk.

17 Lembach: i. m. (14. jegyz.) 86 sk.

18 Ezen növények virágzását Polunin és Huxley vizsgálta, amelynek alapján több hónap eltérést állapítottak meg a három különböző virág esetében. O. Polunin - A. Huxley: Flowers of the Mediterranean. London 1981. 219-224.

19 Ov. fast. IV, 437-442; Ov. met. V, 391.

${ }^{20}$ N. Richardson: The Homeric Hymn to Demeter. Oxford 1974. 143-144 és Lembach: i. m. (14. jegyz.) $86-88$.

${ }^{21}$ Hom. h.Cer. 8-18.

${ }^{22}$ Richardson: i. m. (20. jegyz.) 141 sk.

${ }^{23}$ Paus. 8. 31.

24 Paus. 2. 13. 5, 5. 17. 3

${ }_{25}$ Ceres ülőhelyéről lásd Beschi: i. m. (4. jegyz.) 122-130. 
követően először ment Eleusisba. ${ }^{26}$ Másrészt az istennőt egy sziklára ültették akkor is, amikor nem az eleusisi mítoszkörhöz köthető kontextusban akarták ábrázolni. Így például Pausanias közli velünk a Phigaleiában, Arkadiában, Démétér Melaina templomában található kultuszszoborral kapcsolatban, hogy egy sziklán foglal helyet. ${ }^{27}$ Ebben az esetben a szikla Démétér földdel való kapcsolatát jelképezi, mint az ősi etimológiában, amely szerint neve Ge-meter, a földmérő, a Földanya jelentéssel bír. ${ }^{28}$ Ceres is szorosan kapcsolódik a földhöz: Varro tér ki az istennő, a föld és az anyaság kapcsolatára. ${ }^{29}$ A klasszikus művészetben Démétér és Ceres földhöz kötődő ábrázolása más módon is kifejeződhet, például Tellus megjelenítésével. Az utóbbi istenséget általában a földből kiemelkedve vagy a földre támaszkodva, fekvő helyzetben ábrázolják, mint a föld megszemélyesítését. ${ }^{30} \mathrm{Az}$ Ara Pacis ábrázolásán azonban a sziklán ül az alak, egyértelműsítve a kapcsolatot a trón és az istennő között.

Az Ara Pacison ábrázolt alak drapériájának részletei szintén a Ceresszel való azonosítást támogatják. Ennek az asszonynak külső ruhája egy nagy köpeny, amelyet fátyolként húz fel fejére. A fátyol megjelenése az Ara Pacison ellentétes mind Tellus, mind pedig Italia megjelenítésével: Tellust következetesen fedetlen fejjel, Italiát pedig vagy sisakkal, vagy fedetlen fövel ábrázolják. ${ }^{31}$ A görög-római mủvészetben és irodalomban azonban Démétér/Ceres gyakran visel fátylat, ${ }^{32}$ amelyet a lánya elrablása miatti gyász szimbólumaként értelmeznek. Az ábrázoláson szintén látható az alak alsó vékony ruhája, amely lecsúszik jobb válláról. Galinsky hasonlította össze ezt a ruhanemüt Aphrodité/Venus hasonló ábrázolásaival. ${ }^{33}$ Ugyanakkor az említett ruhadarab Ceres ábrázolásain is megjelenik, például az aricciai Ceres-büsztön, amelyen a corona spicea mellett szintén ugyanilyen, jobb válláról lecsúszó ruhadarabbal ábrázolják az istennőt. ${ }^{34}$ Fontos, hogy a panelen nagy hangsúlyt fektetnek a mellre, amely ebben a reprezentációban a termékenységre és a táplálásra utal, megfelelően Démétér és Ceres funkciójának.

Az Ara Pacis gyermekalakjainak kezében megjelenő gyümölcsök is utalhatnak Ceresre. A görögök Démétért a Kaipophoros 'gyümölcshordozó' melléknévvel is illették, míg a rómaiak Ceres Frugiferának és Mater Frugumnak, gyümölcshozó anyának hívták. ${ }^{35}$ Varro „gyümölcsöző Ceresnek” nevezi. ${ }^{36}$ Az Ara Pacis reliefjén ábrázolt gyümölcsfajták mindegyike, a gránátalma, a szőlő és a dió is kötődik Démétér/Ceres kultu-

${ }^{26}$ Richardson: i. m. (20. jegyz.) 219-221.

27 Paus. 8. 42.

28 A. Pease: Marcus Tullius Cicero: De Natura Deorum. Cambridge 1955-1958. 272 sk.

${ }_{29}$ Varro rust. 3. 1. 4: nec sine causa terram eandem appellabant matrem et Cererem.

${ }^{30}$ A. Van Buren: The Ara Pacis Augustae. JRS 3 (1913) 135-136.

31 Berczelly: i. m. (1. jegyz.) 94 sk.

${ }^{32}$ De Angeli: i. m. (2. jegyz.) 31 sk.

33 Galinsky: i. m. (1. jegyz.) 470-471.

${ }^{34}$ Lásd bővebben Museo Nazionale Romano 112375. leltári szám. Az összehasonlítást elvégezte De Angeli: i. m. (2. jegyz.) 23 sk.

35 A Kaipophoros elnevezésre lásd Farnell: i. m. (3. jegyz.) 32 és Muthmann: i. m. (8. jegyz.) 71 sk. összegzéseit. Ceres „gyümölcshozó” mellékneveihez vö. Ov. fast. I, 671 és Ov. met. VI, 118.

${ }^{36}$ Varro l. l. 5. 64: Quod gerit fruges, Ceres, antiquis enim quod nunc $G$ C. 
szához. A gránátalma az istennő ábrázolásainak fontos kísérője, különösen a Persephoné-mítosz fényében. ${ }^{37}$ Démétér Malophoros szicíliai Selinusban található szentélyében az istennő kultuszszobrát gránátalmával ábrázolták, és ennek a gyümölcsnek votív terrakotta másait is feltárták itt. ${ }^{38} \mathrm{~A}$ mákgubóhoz és a búzához hasonlóan sok magjával a gránátalma is a termékenység szimbóluma, így kapcsolható a Ceres-kultuszhoz. ${ }^{39}$

Az Ara Pacis alakjának más gyümölcsei is utalhatnak erre az istenségre. A szőlő az aventinusi istentriász másik tagjának, Libernek az attribútuma. ${ }^{40} \mathrm{~A}$ gyümölcsök között látható dió szintén termékenységszimbólum. A diófélék a római esküvői szertartások során ugyanúgy megjelentek, akárcsak napjainkban a rizs. ${ }^{41}$ A diót Cerealia ünnepén a felvonulás szemlélői közé dobták. ${ }^{42}$ Az Ara Pacis figurájához kapcsolódó gyümölcsök tehát úgy értelmezhetőek, mint amelyek kiemelik Ceresnek mint termékenységistennőnek a mezőgazdaság termékenységében betöltött szerepét. A panelen látható gyermekek szimbolizálják Ceresnek mint a gyermekek anyjának vagy nevelőjének szerepét az emberi termékenységben. ${ }^{43}$ Mint láthattuk, mind a görög, mind a római kultuszban az istennőt a gyermekek nevelőjeként tisztelték, mint Démétér Kourotrophos és Ceres Mater. A görög és a latin irodalomban különböző gyermekek anyja vagy nevelőanyja (Persephoné, Iakchos, Triptolemos). A görög művészetben Démétért gyakran gyermekkel az ölében ábrázolják, ez az úgynevezett kurotrophos-típus. Például a már említett Selinusban található Démétér Malophoros-szentély szobrocskájának ábrázolásán az istennő ölében tartja gyermekét, aki kezét melle felé nyújtja olyan mozdulattal, amely emlékeztet az Ara Pacis reliefjének figurájára. ${ }^{44}$ Fontos tényező lehet az ábrázoláson látható gyermekek száma is. Két gyermek látható azokon a fogadalmi ajándékokon, amelyeket közép- és dél-olaszországi, valamint szicíliai lelőhelyeken tártak fel. Ezeken a votív ábrázolásokon dajka vagy anya figurája tünik fel gyermekek kíséretében. Példa lehet erre a szicíliai Megara Hyblaea ókori városában feltárt szobor. ${ }^{45} \mathrm{Ez}$ a típus valószínüsíthetően nem ősi itáliai, hanem görög eredetű lehet, mivel az anyaság témája és különösen az ápoló, nevelő anya képe nem ritka a görög művészetben. ${ }^{46}$ Ugyanakkor ezen ábrázolási mód nehezen hozható összefüggésbe az Ara Pacis két gyermekalakjával, sokkal inkább

${ }^{37}$ A Proserpina-mítosz és a gránátalma kapcsolatát feldolgozta Muthmann: i. m. (8. jegyz.) 67-77; Hom. h.Cer. 370-374, 405-413; Ovid. Met. V, 535-539.

${ }^{38}$ D. White: The Post-Classical Cult of Malophoros at Selinus. AJA 71 (1967) 335-352.

${ }^{39}$ Muthmann: i. m. (8. jegyz.) 77 sk.

${ }^{40}$ H. Le Bonniec: Le culte de Cérès a Rome des origines à la fin de la République. Paris 1958. 297 sk.

41 Spaeth: i. m. (1. jegyz.) 129 sk.

42 Le Bonniec: i. m. (40. jegyz.) 114-115 sk.

43 Spaeth: i. m. (1. jegyz.) 41 sk.

${ }^{44}$ G. Zuntz: Persephone: Three Essays on Religion and Thought in Magna Graecia. Oxford 1971.112 sk. Ugyanakkor Zuntz arra is felhívja a figyelmet, hogy az említett ábrázoláson nyilvánvalóan egy fiatalabb nő szerepel, így akár maga Persephoné is lehet. Démétérnek és Persephonénak a megkülönböztetése a különböző ábrázolásokon igen nehéz. Ugyanakkor Zuntz kiemeli, hogy Selinusban ugyanilyen szobrot tártak fel, ahol egyértelműen látható, hogy idősebb női alakot ábrázol.

${ }^{45}$ E. Langlotz - M. Hirmer: The Art of Magna Graecia. London 1965. 17 sk.

46 Spaeth: i. m. (1. jegyz.) 44 sk. 
az itáliai modell befolyásolta az istennő bemutatását a reliefen. A két gyermek mitológiai magyarázata származhat a Cicerónál megőrződött mítoszváltozatból is, amely szerint Liber és Libera is Cerestől származik. ${ }^{47} \mathrm{~A}$ reliefen látható gyermekek neme nincs meghatározva, egyes kutatók szerint szándékosan, hogy többirányú értelemezhetőséget tegyen lehetővé. ${ }^{48}$ Ugyanakkor valószínűsíthető, hogy nemüknek nincs, számuknak viszont van jelentősége.

Végül a központi alak lábánál megjelenő tehén és juh szintén kapcsolatban áll Ceresszel. A Peloponnésoson található Lycosurában, Démétér szentélyében számos terrakotta votív szobrot tártak fel, köztük fátyollal fedett tehén- vagy juhfejjel ábrázolt női alakokat. ${ }^{49}$ Ezek az állatok az istennőhöz tartoztak, mint a mezőgazdasági munka, az állattenyésztés és állattartás jelképei. Varro felhívja a figyelmünket arra, hogy a marha az emberiség társa a mezei munkában, és Ceres szolgája. ${ }^{50} \mathrm{~A}$ mítosz szerint Ceres volt az első, aki háziasította a marhákat, és bevonta őket a mezőgazdasági munkába. ${ }^{51}$ Egy ékszeres gemmán pedig az istennő úgy tünik fel, hogy bikán lovagol, kezében mákot, búzaszálakat és fáklyát tart. ${ }^{52} \mathrm{~A}$ lyciai Xanthusban található Harpy-sír nyugati oldalán Démétért úgy ábrázolják, hogy egy tehén és egy borjú előtt áll. ${ }^{53}$ Ugyanakkor Pausanias arról is beszámol, hogy a görög kultuszban Démétérnek szarvasmarha-áldozatot is bemutattak. ${ }^{54}$ Megjegyzi ugyanis, hogy a peloponnésosi Hermionéban a Pronon-hegyen található szentélyben a szarvasmarhákat rendszeresen feláldozták Démétérnek. Ezt a tényt támasztja alá az is, hogy számtalan szarvasmarhacsontot tártak fel Démétér szentélyeiben Knidosban és Knóssosban. ${ }^{55}$

Bár a görög kultuszban ritkán jelennek meg a juhok Démétérrel összefüggésben, a római forrásokban Ceres kultuszában van szerepük. ${ }^{56}$ Vergilius egy tavaszi mezőgazdasági szakrális rituálét mutat be, amelyben egy juhot vezetnek körbe háromszor a termények körül az áldozat bemutatása előtt. ${ }^{57} \mathrm{Az}$ Aeneisben Dido és Anna áldoz juho-

${ }^{47}$ Cic. N. D. 2. 62: Cerere nati nominati sunt Liber et Libera.

${ }^{48}$ Létezik olyan értelmezés is, hogy a két gyermek Gaius és Lucius Caesart ábrázolja: Spaeth: i. m. (1. jegyz.) $141 \mathrm{sk}$. Viszont azt is látni kell, hogy abban a szobrászati programban, amelyet a dolgozat vizsgál, ez a lehetőség nem értelmezhető. Wlosok véleménye szerint a két gyermek és a női alak Venusra vonatkozik, ahol geminorum mater Amorumként ábrázolják, ahogy azt Ovidius is írja (Ov. fast. IV, 1). A feltételezett Venus-ábrázolásról bővebben lásd A. Wlosok: Geminorum Mater Amorum. In: Monumentum Chiloniense: Studien zur augusteischen Zeit. Kieler Festschrift für Erich Burck zum 70. Geburtstag. Ed. E. Lefèvre. Amsterdam 1975. 514-523.

49 B. Dietrich: Demeter, Erinys, Artemis. Hermes 90 (1962) 140 sk.

50 Varro rust. 2. 5. 3: rietus hominum rustico opere et Cereris minister.

51 Ov. fast. IV, 403-404; Ov. am. III, 10. 13-14.

52 Farnell: i. m. (3. jegyz.) 220 sk.

${ }^{53}$ Muthman: i. m. (8. jegyz.) 73-77 sk. Muthman arra is rámutat, hogy a Démétér-ábrázolással szemben egy virágot és gránátalmát tartó Persephoné-ábrázolás látható.

${ }^{54}$ Paus. 2. 35. 6-8.

${ }^{55}$ E. Bevan: Representations of Animals in Sanctuaries of Artemis and Other Olympian Deities. Oxford 1986. 82 sk.

56 Bevan: i. m. (55. jegyz.) 86.

57 Verg. geor. I, 338-350. 
kat Ceresnek és több más istenségnek Dido esküvője előtt, amelyett Aeneasszal kötött volna. ${ }^{58}$ Ezen kívül egyes kutatók úgy vélik, hogy Démétér kultikus epitheton ornansa, a Malophoros ('juhhordozó') is utal az istennő és a juhok kapcsolatára. ${ }^{59}$

Az Ara Pacis reliefjén a tehén és a juh tehát tükrözik Démétér/Ceres szerepét termékenységistennőként és a mezőgazdasági, illetve pásztori munkák védelmezőjeként. ${ }^{60}$ A különböző motívumok, az Ara Pacis paneljének központi alakjával összefüggésben megjelenő ikonográfiai kapcsolatok alapján tehát a szakirodalomban megjelenő változatos értelmezési irányok ellenére egyértelműnek látszik, hogy a relief középpontjában megjelenő alak Ceres istennő. Az ehhez az alakhoz tartozó attribútumok némelyike szinte kizárólag Cereshez tartozik, például a corona spicea, a búzaszálak és a mákgubók. Ezek az attribútumok mutatják az istennő kapcsolatát a mezőgazdasági termékenységgel, különösen a gabonatermesztéssel.

A központi alak egyéb jellemzői is szorosan kapcsolódnak az istennőhöz annak ellenére, hogy más istenekkel is kapcsolatba hozhatók. A fejen található fátyol Aphrodité/Venushoz kötődik, a gyümölcsök, a gyermekek és az állatok Gaia/Tellushoz. ${ }^{61}$ Ezen képi motívumok - mint már említettük - szintén utalnak a termékenységre. A tény, hogy ezen motívumok különféle női deitásokhoz egyaránt hozzárendelhetők, egyszerűen abból következik, hogy az összes női istenség ikonográfiája hasonló. Másrészről ez a sokszínűség az istenségek szinkretizálására történő szándékos kísérletként is magyarázható. Fontos megjegyezni, hogy mind Venus, mind Tellus szoros kultikus kapcsolatban álltak Ceresszel. ${ }^{62}$ Ugyanakkor mindebben Augustus politikai üzenete is világosan felfedezhető. Az Ara Pacis reliefje központi alakjának többértékű attribútumai lehetőséget teremtenek arra, hogy egyesítsék Ceres istennőt az említett istenségekkel, így fejezve ki azon óhajt, hogy az istennő tartsa meg örök időkre Itália földjének termékenységét. Ez lehetővé tenné a relief poliszemantikus értelmezését, amint azt számos kutatás javasolta. ${ }^{63}$ Ugyanakkor Ceres elsődlegessége mellett (nem kizárva a Venusra és Tellusra vonatkoztatható másodlagos utalások szintjét sem) nemcsak az alak attribútumainak vizsgálatával lehet érvelni, hanem a képnek az augustusi propagandában való elhelyezésével is.

58 Verg. Aen. IV, 56-59.

${ }^{59}$ N. Hopkinson: Callimachus: Hymn to Demeter. Cambridge 1984. 185 sk.

${ }^{60}$ Semmiképpen nem mehetünk el azon tény mellett, hogy Démétér görög kultuszában az egyik legjelentősebb állat a sertés, ami viszont a reliefen egyáltalán nem jelenik meg. Fontos kiemelni, hogy a Hellas területén található Démétér-kultuszhelyek többségén bizonyíthatóan áldoztak sertést az istennő számára. Itáliában semmi nyoma ennek, sőt fentebb olvasható, hogy a szicíliai lelőhelyeken kizárólag marhaáldozatra utaló nyomokat találtak. A dolgozat strukturális és terjedelmi határai miatt ezen probléma tárgyalására itt nincs lehetőség, erről bővebben lásd Langlotz - Hirmer i. m. (45. jegyz.) 17 sk. Spaeth: i. m. (1. jegyz.) 131-132 sk. megoldási javaslata gyenge lábakon áll.

${ }^{61}$ E. Strong: Terra Mater or Italia? JRS 27 (1937) 115-118 sk.

62 Spaeth: i. m. (1. jegyz.) 103-105.

${ }^{63}$ Galinsky: i. m. (1. jegyz.) 468-475. 
Augustus uralmának kezdetével egy olyan új korszak köszöntött be, amely gyökeresen változtatta meg a római társadalmat, bár eredeti célja az volt, hogy ez ne tünjön így. Augustus a köztársaság intézményeit használta fel arra, hogy megszilárdítsa hatalmát, és a hivatalokon keresztül fokozatosan erősítette meg egyeduralmát. Augustus hatalomra kerülése nemcsak politikailag értelmezhető, hanem a társadalomra, a kultúrára és a vallásra is döntő hatással volt. Wallace-Hadrill megfogalmazásában a politikai forradalmat az alapvető és átfogó elemek egyik részeként kell értelmezni az új társadalmi, vallási és kulturális formák kialakulásában. ${ }^{64}$ Természetesen ahhoz, hogy a hatalmat megtartsa, Augustusnak szüksége volt a senatusra, amelyet még mindig a régi római családok tagjai alkottak, bár a szük kör uralma lényegével megszünt. Gelzer szerint a domináns elit túl merev, a köztársaság müködése pedig túlságosan mechanikus volt. ${ }^{65}$ Az elit dominanciájának fontos szerepe volt a vallásban és a rítusok fenntartásában. ${ }^{66}$ Ebben a modellben az egyeduralkodó megjelenésével létrejött egy új tényező, ő pedig igyekezett saját magához vonni ezen eszközöket. Mindez radikális átalakulást eredményezett, amely újradefiniálta a római identitást és a római kultúrát. ${ }^{67}$

Augustusnak a politikai programja elterjesztéséhez hatékony propagandára volt szüksége, mely a vallási életre is kiterjedt. Az új rendszer egyik fontos mondanivalóját kiválóan megjelenítette a mezőgazdaság és a gabona istennője, Ceres. Ceresnek az aventinusi istenhármas tagjaként jelentős kultusza alakult ki a társadalom alsóbb rétegeiben, ezt pedig Augustus komoly politikai tőkévé tudta kovácsolni. Egy olyan birodalomban, ahol kiemelt jelentőségü volt a gabona szerepe, propagandisztikus eszközökkel saját személyéhez tudta kötni az istennőt, s ezzel közvetve a gabonaellátást is. Ceres mint a princepshez kötődő fontos szimbólum állandó szereplőjévé vált az Augustus-kor politikai propagandájának, amely összekapcsolta őt a termékenységgel, a nőkkel és a populares széles társadalmi csoportjával. A mezőgazdaságnak - és így Ceres istennőnek - volt még egy további fontos aspektusa a rómaiak és az augustusi program (és propaganda) számára. A rómaiak identitásának fontos eleme, hogy a társadalmuk gerincét az önálló, saját kisbirtokkal rendelkező földművesek alkotják. A res publica válsága ennek a rétegnek a megroppanásával járt együtt, és ennek megfelelően az augustusi restauráció és aranykor a régi társadalmi kép helyreállítását is jelentette, legalábbis a propaganda szintjén. Evvel magyarázható ennek az elvékonyodó rétegnek a felülreprezentáltsága és idealizálása az Augustus-kori irodalomban. ${ }^{68}$ Jó példát szolgáltathat erre Horatius két ódájának egymás mellé helyezése: a komor III, 6-ban a kisbirtokos parasztok a gyászos jelennel szembeállított dicső múltnak a képviselői, de az Ara Pacisszal egy időben keletkezett IV, 5-ben már újra ők alkotják az augustusi aranykor római társadalmát. ${ }^{69}$

${ }^{64}$ A. Wallace-Hadrill: Mutatas Formas: The Augustan Transformation of Roman Knowledge. In: The Cambridge Companion to the Age of Augustus. Ed. K. Galinsky. Cambridge 2007. 55 sk.

${ }_{65}$ M. Gelzer: The Roman Nobility. Oxford 1969. 27 sk.

66 J. North: The Roman Counter-revolution. JRS 79 (1989) 153 sk.

67 Wallace-Hadrill: i. m. (64. jegyz.) 57 sk.

${ }^{68}$ Hegyi W. Gy.: Horatius és Augustus. In: Historia critica. Szerk. Manhercz O. Budapest 2014. 46 sk.

${ }^{69}$ Hegyi W.: i. m. (68. jegyz.) 46-47. 
Horatius valószínűleg nem véletlenül használta fel őket így a műveiben, hiszen Ceres istennővel kapcsolatban ezen alakok kapnak kiemelt szerepet Vergilius és Ovidius müveiben is, vagyis ők az augustusi propaganda eszközei. ${ }^{70}$

A változatos kapcsolatokra irodalmi, numizmatikai, epigráfiai és művészi ábrázolásokon is rámutattunk. Ceres a gyermekek anyjaként, nevelőjeként, a nők pártfogójaként és - mint az Ara Pacison is láthattuk - a béke és a római világ őreként jelenik meg a rómaiak képzeteiben, tevékeny szerepet vállal a béke helyreállításában, alakjának és ábrázolásának elsődleges üzenete tehát a Pax Augusta ünnepe a római világban.

\section{A panel oldalsó figurái}

Felvetődhet rögtön az a megoldás, hogy az Ara Pacis reliefjén megjelenő mellékalakokat pusztán a helykitöltés eszközének, díszítő elemnek tekintjük, melyeknek nincs kapcsolatuk a központi figurával. Galinsky ezzel szemben azt állítja, hogy fontos kapcsolat lehet a három alak között. ${ }^{71}$ Spaeth javasolja, hogy az alakokat vízi nimfákként értelmezzük: a jobb oldalit néreisként, tengeri nimfaként, a bal oldalit pedig naiádként, a források és a tavasz nimfájaként. A bal oldalon álló alakot leggyakrabban a Levegő, míg a jobbra elhelyezkedőt a Víz perszonifikációjaként azonosítják. ${ }^{72}$ Ugyanakkor De Grummond is rámutatott arra, hogy ez az azonosítás nem feltétlenül helytálló. ${ }^{73}$

Ikonográfiailag az alakokat Levegőként (Aura) és Vízként azonosítják a fejük felett lebegő fátyol (velificatio) miatt. ${ }^{74} \mathrm{~A} z$ Aura és a velificatio motívumához kapcsolódóan idősebb Plinius is közöl egy domborműleírást a Porticus Octaviaeról, amelyen két Aura vitorlát formál ruháiból, ${ }^{75}$ így kapcsolódnak az Ara Pacison szereplő figurákhoz. Ezzel kapcsolatban gyakran utalnak még Horatius soraira:

\section{Fertilis frugum pecorisque Tellus \\ spicea donet Cererem corona, nutriant fetus et aquae salubres et Iovis aurae.}

(Hor. Saec. 29-32.)

Ezen interpretáció alapján a dombormü központi alakjaként Tellus jelenik meg, míg a két oldalsó figura két Aura. Tellus corona spiceát visel, utódokat és gyümölcsöket tart az ölében, és lábainál nyája látható. Aura is jól felismerhető az istennő oldalán a hullámzó

${ }^{70}$ Ceres és a földművelők: Verg. Ecl. V, 78-79, Verg. geor. I, 94-99, 147-149, 160-168, 338-350; Ov. am. III, 2. 53; Ov. fast. I, 695-704; IV, 401-412.

${ }^{71}$ K. Galinsky: Venus on a Relief of the Ara Pacis Augustae. AJA 70 (1969) 203-204 sk.

72 Spaeth: i. m. (1. jegyz.) 67 sk.

${ }^{73}$ De Grummond: i. m. (1. jegyz.) 669 sk.

${ }^{74}$ Simon: i. m. (1. jegyz.) 27 sk.

75 Plin. nat. 36. 29. 
fátyolról. Mindez azonban számos problémát vet fel. Először is a velificatio nem kizárólag a levegőnimfához kapcsolódó jelenség, sok más istenségnek és félistennek vannak kapcsolatai ezen ábrázolásmóddal. ${ }^{76}$ Továbbá fontos hangsúlyozni, hogy a velificatio az Ara Pacis dombormüve két oldalsó alakjához tartozó tulajdonságok közül csak egy. Ez az értelmezés figyelmen kívül hagyja a coronákat, amelyeket viselnek, valamint azon lényeket és növényeket, amelyeken nyugszanak, holott ezen attribútumok figyelembevétele elengedhetetlen az oldalsó figurák értelmezése esetén.

Spaeth szerint az alakok vízi nimfákkal történő azonosítása cáfolja azt az elméletet, miszerint a figurák levegőnimfák lennének. Itt meg kell jegyezni, hogy számos ábrázolási sajátosság utal Spaeth megoldására, ezenkívül az ábrázolás ezen értelmezése rámutat arra, hogy jelentőségük van a kompozíció egészének megértése szempontjából. Itáliában a nimfák kultusza a Kr. e. VI. századig vezethető vissza. Fontos szerephez Caesar és Augustus idején jutottak, és tiszteletük gyorsan elterjedt a birodalom területén a principátus korai időszakában. A római vallásban azonban nincs nyoma annak, hogy a levegőnimfáknak (aurae) bármilyen hagyománya lenne. A nimfáknak emellett fontos szerepük van Démétér/Ceres mítoszaiban, kultuszaiban és a hozzájuk kapcsolódó müvészeti ábrázolásokban is. Ez a kapcsolat pedig az Ara Pacis reliefjén különféle értelmezési és ábrázolási szinteken is értelmezhető.

A relief jobb oldalán található ábra tulajdonságai alátámasztják azon feltevést, hogy az alak egy néreida. Tengeri sárkányon vagy ketoson lovagol, amely a tenger hullámai közül emelkedik ki. ${ }^{77}$ A ketosok alapvető jellemzői a kutyafej, a nagy, felálló fülek, a nyitott száj és a pikkelyes, hullámzó testforma. A ketoson lévő néreida motívuma különösen népszerü volt a görög müvészetben, és a rómaiak is alkalmazták a tengeri istenségek és a hozzájuk kapcsolódó thiasosok ábrázolására. ${ }^{78}$ Idősebb Plinius is úgy írja le a Néreidákat, mint akik delfinen, ketoson vagy hippokamposon ülnek. ${ }^{79}$ Ovidius a Nap palotájának leírásakor a következőképpen jellemzi Doris leányait:

Doridaque et natas, quarum pars nare videtur,

pars in mole sedens viridis siccare capillos

pisce vehi quaedam...

(Ov. met. 2. 11-14.)

Az Ara Pacison ábrázolt alakok többi attribútuma is kapcsolódhat a néreidákhoz. Az ábrázolt alak coronát hord, melynek részletei azonban nem kivehetőek. A fenti idézetben Ovidius zöld hajúnak írja le a néreidákat, ami a hajban lévő, vagy talán a corona anyagát

${ }^{76}$ A velificatio ábrázolásával foglalkozik bővebben F. Matz: Der Gott auf dem Elephantwagen. Mainz 1952. 725-728. Ezen mủ alapján számtalan deitás kapcsolatba hozható a velificatióval, mint a Néreides, Horae, Maenades, Niobé, Selené, Hélios, Európé, Dionysos, Ariadné, Poseidón és Aphrodité, hogy csak a jelentősebbeket említsük.

77 K. Shepard: The Fish-Tailed Monster in Greek and Etruscan Art. New York 1940. 29 sk.

78 D. Levi: Antioch Mosaic Pavements. Rome 1971. 101 sk.

79 Plin. nat. 36. 26 
alkotó algára vonatkozik. Az Ara Pacis reliefjén szereplő nimfákat gyakran meztelenül vagy félmeztelenül ábrázolták. Spaeth rámutat arra, hogy ennek legközelebbi párhuzamát a peloponnésosi Lykosura Démétér-szentélyében találjuk. Ez az ikonográfiai hasonlóság afelé mutat, hogy az Ara Pacis domborműve jobb oldali alakját tengeri nimfaként is értelmezhetjük. ${ }^{80}$

A dombormű bal oldali alakjának jellemzői azt sugallják, hogy naiast ábrázol. A nőalak egy nagy vízimadáron, lúdon, esetleg hattyún lovagol. A madár funkcióját nehéz meghatározni, mivel a vízimadarak természetes módon kapcsolódtak a vízhez kötődő istenségekhez, ahogyan például a lúd összekapcsolódott Herkyna nimfa történetével. ${ }^{81}$ Ugyanakkor a lúd és a hattyú a nimfák természetes attribútuma lehet vízközeli életmódjuk miatt, amelynek következtében az antik irodalomban is szorosan kötődnek a folyókhoz, tavakhoz és a mocsarakhoz. ${ }^{82}$ Numizmatikai leletek rámutatnak arra, hogy Magna Graeciában, Kamarina városában számos görög didrachmán ábrázoltak hattyún ülő női alakokat, ${ }^{83}$ felettük a velificatio megjelenítésével.

Fontos megvizsgálnunk a bal oldali alak környezetét is. Egy mocsaras jelenet látható az azonosítást segítő számos apró részlettel, amelyek közül az egyik legszembetünőbb az oldalán fekvő amphora, amelyből víz ömlik ki. De Grummond mutatott rá arra, hogy az amphora a nimfák egyik fontos attribútuma: ${ }^{84}$ a belőle kiömlő vízfolyás patakot vagy forrást szimbolizálhat, amelynek öre a nimfa.

Démétér/Ceres és a nimfák együttes megjelenítése az Ara Pacison nem meglepő, figyelembe véve vallási és mitológiai összefüggéseiket. A szakirodalomban már alaposan tanulmányozták Ceres vízzel való kapcsolatát mind a tenger, mind az édesvíz vonatkozásában. ${ }^{85}$ Persephoné elrablásának több verziójában is fontos szerep jut a vízi istenségeknek. Az elrablásakor Persephonéval levő társait különféleképpen azonosítják, lehetnek vízi nimfák, szirének, esetleg Achelóos folyamisten lányai. ${ }^{86}$ Más mítoszokban Démétér számos esetben kerül kapcsolatba vízi istenségekkel, többek között a Néreidákkal és Poseidónnal, Ókeanosszal, valamint a Danaidákkal. Pindaros állítása szerint Démétérnek a nimfákkal együtt mutattak be áldozatot, ${ }^{87}$ amit régészeti leletek is alátámasztanak. Muthmann és Piccaluga is rámutat arra, hogy Démétér kultuszhelyei általában víz közelében voltak, tenger vagy édesvizek mellett. Ezeken a helyeken külön-

80 Spaeth: i. m. (1. jegyz.) 136 sk.

81 Paus. 9. 39. 2.

${ }^{82}$ H. Gossen: Schwan. PWRE 1923. 788 sk.

${ }^{83}$ Fontos megjegyezni, hogy ezen leletek ábrázolásukat tekintve csábítóan komoly párhuzamokat mutatnak az Ara Pacis bal oldali nőalakjával, amit a szakirodalom, mint Spaeth: i. m. (1. jegyz.) 136 sk., valamint De Grummond: i. m. (1. jegyz.) 669 sk. bizonyító erejűnek vél. Ugyanakkor látni kell, hogy a numizmatikai ábrázolásokat egyáltalán nem tudjuk biztonsággal a nimfákhoz kapcsolni, sem pedig a Démétér/Cereskultuszhoz. U. Westermark - K. Jenkins: The Coinage of Kamarina. London 1980. 59-71 véleménye szerint a Kamarina melletti tó megszemélyesítése lehet a női alak, így lényegében egy naias.

${ }^{84}$ De Grummond: i. m. (1. jegyz.) 700 sk.

85 G. Piccaluga: Il corteggio di Persephone. Minutal: Saggi di storia delle religioni. Róma 1974. 36-77.

86 Ókeanos: Hom. h.Cer, 5; szirének: Ov. met. V, 551-555.

87 Pind ol. 1. 13. 74. 
leges intézkedéseket is foganatosítottak arra vonatkozóan, hogy a vizet milyen módon lehet felhasználni a rituálék során. ${ }^{88} \mathrm{~A}$ római kultuszban is van kapcsolat Ceres és a nimfák között. Ostiában egy márvány putealon látható felirat szerint Ceres istennőnek és a nimfáknak szentelték fel azt. ${ }^{89}$

Ceres és a nimfák együttes megjelenítése az Ara Pacison különféle jelentéseket fejez ki. A nimfák az esővel való kapcsolatuk révén a vegetatív növekedés és termékenység istennői is. ${ }^{90} \mathrm{~A}$ vízi nimfák az istennő tápláló erejét jelképezik a vízen keresztül, így Ceres termékenységi aspektusa elevenedik fel. A nimfák egyúttal a tavasz istenségei, akiket virágokkal és kertekkel azonosítanak, ${ }^{91} \mathrm{~s}$ ez szintén jól magyarázza a Ceresszel való ábrázolást.

A nimfáknak nemcsak a növényi termékenységre, hanem Cereshez hasonlóan az állati és az emberi fertilitásra is értelmezhető isteni szerepük van. Táplálékot szolgáltatnak az állatállomány számára, mítoszaik összekapcsolódnak az állatokhoz kötődő más istenségekkel: Faunusszal, Pannal és Apollóval. Különböző mitikus történetekben a nimfák gyakran a gyermekek ápolóiként jelennek meg, hasonlóan Dionysushoz, Hermaphroditushoz és Iuppiterhez..$^{92}$

Kenner mutatott rá arra, hogy Cereshez hasonlóan a nimfák esetében is megjelenik az úgynevezett kurotrophos típusú ábrázolás. ${ }^{93}$ Amint láttuk, a nimfák által táplált növények, állatok és gyermekek Démétér és Ceres központi alakjának attribútumai, amelyek megjelennek az Ara Pacis domborművén. Ezen a szinten tehát a dombormű nimfái szimbolizálják az istennő által nyújtott éltető táplálékot.

Spaeth véleménye szerint a nimfák egy másik értelmezési szintet hoznak müködésbe, amennyiben időjárási jelenségekre utalnak. ${ }^{94}$ Ahhoz, hogy megértsük ezen kapcsolódási pontokat, érdemes megvizsgálnunk Vergilius Georgicájának egy hosszabb részletét, elsőként az I, 335-350-ig terjedő sorokat:

hoc metuens caeli mensis et sidera serua,

frigida Saturni sese quo stella receptet,

quos ignis caelo Cyllenius erret in orbis.

in primis uenerare deos, atque annua magnae

${ }^{88}$ Piccaluga: i. m. (85. jegyz.) 62-64 sk. és Spaeth: i. m. (1. jegyz.) 67 sk. gyűjtése alapján forrás mellett létesült Pellené, Athén, Patrai, Platea és Andania szentélye. Folyóvíz mellett Argos, Triphyliaka, Lidia és Phigaleia. Tó mellett Kopais és Lerna szentélye. Lebadeiában a szentély mellett egy rituális fürdőt is feltártak. A tenger mellett található Attikában Phaleros szentélye. Muthmann: i. m. (8. jegyz.) 37-41 arra is rámutat, hogy számtalan esetben, mint Kos vagy Eleusis esetében, a tervezés során fontos tényező volt, hogy hol találhatóak a források, így az alapján tervezték meg a szentélyeket.

${ }^{89}$ CIL XIV. 2

90 W. Roscher: Ausführliches Lexikon der griechischen und römischen Mythologie. Leipzig 1884-1937. 515 sk.: Nymphae.

91 Hor. c. 1. 4. 5-12, 4. 7.1-6

92 Roscher: i. m. (90. jegyz.) 515. sk.: Nymphae.

${ }^{93}$ H. Kenner: Das Tellusrelief der Ara Pacis. ÖJh 53 (1981) 36 sk.

94 Spaeth: i. m. (1. jegyz.) 138 sk. 


\begin{abstract}
sacra refer Cereri laetis operatus in herbis extremae sub casum hiemis, iam uere sereno. tum pingues agni et tum mollissima uina, tum somni dulces densaeque in montibus umbrae. cuncta tibi Cererem pubes agrestis adoret: cui tu lacte fauos et miti dilue Baccho, terque nouas circum felix eat hostia fruges, omnis quam chorus et socii comitentur ouantes et Cererem clamore uocent in tecta; neque ante falcem maturis quisquam supponat aristis quam Cereri torta redimitus tempora quercu det motus incompositos et carmina dicat.
\end{abstract}

(Verg. geor. I, 335-350)

Itt egy olyan mezőgazdasági istenség tűnik fel előttünk, akinek jóindulatát kell keresni, és akinek hatalma megóvja az állatokat és a terményt, mielőtt az ember elvégezné a rendes mezőgazdasági munkákat. Ceres mezőgazdasági rítusai magukba foglalják a mezők rituális tisztítását, egy vidéki betakarítási ünnep szertartásos énekeit és táncait, valamint a betakarítás első gyümölcsének felajánlását. Ebben a részletben jól kivehetőek a tavasz közeledtével elvégzendő szertartások, melyeknek egy célja van, hogy az istennő kegyes legyen, és az állatoknak, növényeknek megfelelő szaporulatot adjon, így biztosítsa az emberek jólétét. Az istennő funkciói közül kiemelkedik a mezőgazdaság támogatása és a termékenység biztosítása. ${ }^{95}$ Azonban érdemes megvizsgálnunk a közvetlenül ezt követő I, 351-359-ig terjedő részletet is, hiszen hasonlóan a dombormü jobb oldalán látható képhez, borús, vihar közeledtét jelző leírást láthatunk:

\begin{abstract}
Atque haec ut certis possemus discere signis, aestusque pluuiasque et agentis frigora uentos, ipse pater statuit quid menstrua luna moneret, quo signo caderent Austri, quid saepe uidentes agricolae propius stabulis armenta tenerent. continuo uentis surgentibus aut freta ponti incipiunt agitata tumescere et aridus altis montibus audiri fragor, aut resonantia longe litora misceri et nemorum increbrescere murmur.
\end{abstract}

(Verg. geor. I, 351-359)

95 A korabeli forrásokban megfigyelhető, hogy Ceres erősen kapcsolódik a földekhez, mezőkhöz, a földművesekhez, gabonához és általában véve a kenyérhez. Ceres és a föld: Hor Carm. Saec. 29-32, Ov. fast. I, 671-674. 
Ha végigolvassuk a fentebb tárgyalt két részletet, akkor ugyanazt a kettősséget tapasztaljuk, mint ami az Ara Pacis képi világát is jellemzi. Vergilius a Georgicában ugyanolyan kontextust hoz létre Ceres istennő alakja körül, mint ami a reliefen van. A dombormü bal oldalán látható vízimadár, illetve bármilyen madár viselkedése is összeköthető az időjárással, különösen a viharral, érdemes itt gondolni a madarak nyár végi vonulására, vagy arra, hogy a madarak nagy vihar esetén is elhagyják a területet, folyamatosan menekülnek a vihar elől. Akaratlanul is felmerül a kérdés, hogy véletlen-e az egyezés, vagy esetleg átgondolt ábrázolási programról van szó? A kérdést nem lehet teljes bizonyossággal megválaszolni, de a forrongó tenger, közeledő vihar és a menekülő vízimadár képe mind megtalálhatóak a reliefen és Vergilius müvében is, így nem vethetjük el azt a lehetőséget, hogy az ókori rómaiak számára ezen képek összefonódtak. Azt hihették, hogy ha nem vagy rosszul végzik el a Cereshez kötődő szertartásokat és áldozatokat, akkor ez büntetésként valamilyen úton visszájára fordulhat.

A nimfák felett található velificatio is arra utal, hogy valamilyen esős, már-már viharos képet formáz meg a relief. Nagyon érdekes kettősség ez, hiszen a víz a vegetáció egyik legfontosabb éltető eleme, ugyanakkor a Georgica első könyve rengeteg olyan utalást tartalmaz, amely egy-egy nagyobb vihar pusztítását szemlélteti. Spaeth szerint valószínűleg szándékos ábrázolási módról van szó, amellyel egyfajta kettőséget kívántak szimbolizálni. ${ }^{96} \mathrm{Az}$ állatok nyugalomban foglalnak helyet az istennő lábainál, ahogy a körülöttük lévő növények is nyugalmi állapotban vannak. Ezt a nyugalmat leginkább Ceres központi alakja sugározza azáltal, hogy a sziklatrónon ülve szilárd középpontját képezi a reliefnek. A mezőgazdasági termékenység védelmezőjeként Ceres megóvja mind a növényeket, mind pedig az állatokat a közeledő veszélytől, ahogy a két gyermeken keresztül az emberiséget is oltalmazza. Nem véletlenül figyelmeztet Vergilius arra, hogy féljék Cerest, és mindig mutassák be a neki kijáró áldozatokat. ${ }^{97}$ Ebben az értelmezésben Ceres a római társadalmat jelképezi, egyfajta összeköttetést teremtve az anyagi, gazdasági, termést érintő és a politikai stabilitás között, amelyek mindegyike elengedhetetlen a társadalmi egyensúly tartós fennmaradásához.

A dombormű központi alakja tehát az istennő, aki megvédi a gazdákat és a növényeket a vihar ellen, amelyet a reliefen a két nimfa jelképez. Ez önmagában azonban még gyenge lábakon álló magyarázat lenne a nimfák szerepeltetésére, ezért érdemes megvizsgálni Piccaluga értelmezését, amely szerint a két alak lényegében a két különböző típusú vízre vonatkozik. Az aqua utile, az édesvíz az, ami öntözésre, illetve az emberi és állati fogyasztásra alkalmas, ezáltal létfenntartónak minősül. Ezzel szemben az aqua non utile a nyers természeti erőre, a vízre mint elemre utal. ${ }^{98}$ Ezen értelmezés alapján feltételezhetjük, hogy Cerest mezőgazdasági istenségként a vízzel társítják. Ugyanakkor nem szabad azt hinnünk, hogy a nem felhasználható vagy nem hasznos víznek semmi

\footnotetext{
96 Spaeth: i. m. (1. jegyz.) 139 sk.

97 Verg. geor. I, 338-340.

98 Piccaluga: i. m. (85. jegyz.) 70-76.
} 
köze sincs az istennőhöz. Éppen ellenkezőleg: mindkét víz kötődik hozzá, voltaképpen mindkettő ő maga. Így átvitt értelmezésű magyarázatban a sós víz, aminek sótartalma miatt nincs éltető ereje, mindent kipusztít a földből, és egy nyers természeti erő, illetve az éltető erővel rendelkező édesvíz voltaképpen ugyanannak a dolognak két véglete. Ez a kettőség pedig jól nyomon követhető Ceres esetében, ahogyan azt a gabona példája is mutatja: ami megnőhet, azt a vihar el is pusztíthatja.

Spaeth értelmezése szerint a relief két nimfája Róma kettős eredetére utal: egyfelől az idegen származású, trójai Aeneasra, másfelől az őshonos, itáliai Romulusra és Remusra. A néreida Róma idegen eredetét jelképezi. A latin irodalomban a tengeri nimfák általában görög neveket kapnak, az itáliaiak idegen istenekként tekintenek rájuk. ${ }^{99}$ Vergiliusnál Aeneast, amikor elhagyja Szicíliát és Itáliába indul, görög tengeri istenségek kísérik: Thetis, Melite, Panopea, Nesaea, Spio, Thalia és Cymodocea. A nimfák közül az egyik, Cymodocea figyelmezteti Aeneast Turnusnak a trójai tábor ellen tervezett támadására. ${ }^{100}$ Ezek alapján Spaeth úgy gondolja, hogy az idegen tengeri nimfákat kontrasztba lehet állítani az itáliai forrásokat, kutakat és folyókat védelmező nimfákkal. Az utóbbiak latin nevet viselnek, ősi kultuszokkal rendelkeznek, és szorosan kötődnek Róma korai történelméhez, mint például Iuturna, Camenae vagy Carmentis. Vergilius ${ }^{101}$ és Ovidius $^{102}$ ezeket a nimfákat őshonos isteneknek, indigenae deinek nevezi. Az Aeneisben Evander a következőket mondja Aeneasnak:
tum rex Evandrus Romanae conditor arcis:
'haec nemora indigenae Fauni Nymphaeque tenebant
gensque virum truncis et duro robore nata,
quis neque mos neque cultus erat, nec iungere tauros
aut componere opes norant aut parcere parto,
sed rami atque asper victu venatus alebat.
primus ab aetherio venit Saturnus Olympo
arma Iovis fugiens et regnis exsul ademptis.

(Verg. Aen. VIII, 314-320)

Tehát a nimfák Itália első lakosai voltak még Saturnus eljövetele előtt. Ceres ezek alapján közvetítőként szolgál Róma kettős eredetének két szimbóluma között. ${ }^{103}$

Az Ara Pacis domborművének nimfái tehát sokrétủ jelentéssel bírnak. Az egyik értelmezési síkon a víz tápláló erejét szimbolizálják, amely összekapcsolja őket Ceresszel, így pedig a termékenységgel. A nimfák ugyanakkor a víz pusztító hatását is szimbolizálják, amennyiben az eső és a vihar lehetséges pusztítását jelképezik. Ceres irá-

\footnotetext{
99 C. Bailey: Religion in Virgil. Oxford 1935. 36-3.

100 Verg. Aen. X, 225.

101 Verg. Aen. VIII, 314.

102 Ov. met. VI, 329-330.

103 Spaeth: i. m. (1. jegyz.) 140 sk.
} 
nyítja mind a víz megtermékenyítő, mind elemi pusztító tulajdonságait. Végül a nimfák Róma kettős eredetét is szimbolizálhatják. A különféle értelmezési javaslatokban a dombormű alakjai egységet alkotnak, ezáltal pedig a relief egészének rendkívül összetett jelentést adnak.

\section{A relief politikai üzenete}

Ceres tehát központi szimbólum nemcsak a relief, hanem az Ara Pacis egészének ikonográfiájában, minthogy rendkívül alkalmas az augustusi politika üzenetének továbbítására. A béke, különösen a Pax Augusta az oltár központi témája. Mint láttuk, a béke fogalma szoros kapcsolatban áll Ceresszel mind átmeneti, mind normatív szerepében. ${ }^{104}$ Tibullus a következőket írja:

Quam potius laudandus hic est, quem prole parata occupat in parva pigra senecta casa.

Ipse suas sectatur oves, at filius agnos, et calidam fesso conparat uxor aquam.

Sic ego sim, liceatque caput candescere canis, temporis et prisci facta referre senem.

Interea pax arva colat. Pax candida primum duxit araturos sub iuga curva boves, pax aluit vites et sucos condidit uvae, funderet ut nato testa paterna merum, pace bidens vomerque nitent - at tristia duri militis in tenebris occupat arma situs rusticus e lucoque vehit, male sobrius ipse, uxorem plaustro progeniemque domum.

(Tibull. I, 10, 39-52)

Tibullus békéről írt sorai mintha csak Ceres feladatkörének leírását adnák. Ápolja a mezőket, gondozza a vetést és az állatokat, táplálja a növényeket, a szőlő pedig szintén Ceres attribútuma. A Pax és Ceres közötti hasonlóság máshol is megjelenik a római irodalomban. A Fasti első könyvében Ovidius - Tibullushoz hasonlóan - összekapcsolja Cerest, a Békét és Augustust:

bella diu tenuere viros: erat aptior ensis vomere, cedebat taurus arator equo: sarcula cessabant, versique in pila ligones,

104 Spaeth: i. m. (1. jegyz.) 68 sk. 
factaque de rastri pondere cassis erat. gratia dis domuique tuae; religata catenis iampridem vestro sub pede bella iacent. sub iuga bos veniat, sub terras semen aratas. Pax Cererem nutrit, Pacis alumna Ceres.

(Ov. fast. I, 697-704)

A fenti részletben jól látszik, hogy az istennő alakja mintegy átmenetet képez a polgárháború korát jellemző erőszak és az Augustus által elhozott béke között. Ceres, Pax és Augustus kapcsolatát még egyértelműbbé teszi a Fasti egy másik részlete:

prima Ceres homine ad meliora alimenta vocato

mutavit glandes utiliore cibo.

illa iugo tauros collum praebere coegit:

tum primum soles eruta vidit humus.

aes erat in pretio, chalybeia massa latebat:

eheu! perpetuo debuit illa tegi!

Pace Ceres laeta est; et vos orate, coloni,

perpetuam pacem pacificumque ducem.

(Ov. fast. IV, 401-412)

A központban természetesen Augustus áll, aki békét hozott Itáliába, és megteremtette azt az államalakulatot, amelynek segítségével létrejött a későbbi Imperium Romanum, és ezáltal lehetővé tette, hogy a Ceres istennő által biztosított és ápolt termékenység visszatérjen a földre. A fenti idézetek segítenek nekünk az Ara Pacis politikai üzenetének jobb megértésében: Augustus elhozta és meg is őrzi a békét az istenek jóindulatából. Velleius Paterculusnál a következőket olvashatjuk:

Caesar autem reversus in Italiam atque urbem quo occursu, quo favore hominum omnium generum, aetatium, ordinum exceptus sit, quae magnificentia triumphorum eius, quae fuerit munerum, ne in operis quidem iusti materia, nedum huius tam recisi digne exprimi potest. [...] Rediit cultus agris, sacris honos, securitas hominibus, certa cuique rerum suarum possessio; leges emendatae utiliter, latae salubriter, senatus sine asperitate nec sine severitate lectus.

(Vell. II, 89.)

A senatus Kr. e. 13-ban, Augustus tartományokból való visszatérése alkalmából, hálaadásként rendelte el az Ara Pacis megépítését. ${ }^{105}$ Velleius Paterculus részlete egyértelművé teszi, hogy itt a földművelésnek az ideális uralkodó trónralépését követő újraindulásával és zavartalan működésével van dolgunk, ami Homéros óta kimutatható ősi

${ }^{105}$ M. Putnam: Artifices of Eternity: Horace's Fourth Book of Odes. Ithaca 1986. 327-328. 
toposz. ${ }^{106}$ A romlatlan természet és vidék idillisztikus képe, ahogy mind a görög, mind a római bukolikus szerzőknél megjelenik, ellentétben áll a felfordult, háború dúlta világgal. Ez az ellentétpár a római irodalomtörténetben számtalanszor megjelenik, és mindig nagyon hangsúlyos szerepet kap. ${ }^{107}$

A főalaktól jobbra látható hippokampos viharos tengeren való ábrázolása éppúgy szembeállítható az istennő alakja körül látható idilli képpel, mint a felrebbenő vízimadár, amely éppen a vihar elől menekül. A másik lehetőség, mint azt már említettük, a princeps istenekkel való kapcsolata. Augustus szükségesnek érezte maga mögött tudni szélesebb néprétegek támogatását, minden bizonnyal ezért is építette újjá az aventinusi istenhármas szentélyét. ${ }^{108}$ Ezen szándékot látszik támogatni Ceres Mater és Ops Augusta oltárának felszentelése, valamint az eleusisi misztériumok támogatása is. ${ }^{109}$ Említett intézkedéseit erősítik az általa kiadott érmék, amelyeken Ceres, illetve valamelyik attribútuma jelenik meg, így a kibocsátó Augustus önmagát a köznép védelmezőjeként és támogatójaként reprezentálhatta. ${ }^{110}$ Harmadik magyarázatunkat politikai és gazdasági tényezők egyaránt támogatják. Róma gabonaszükségletének kielégítése számos esetben okozott gondot a Város vezetésének. Augustus számára különösen fontos volt a gabonaellátás folyamatos biztosítása, ha pedig lehetőség nyílt rá, sok esetben tartott gabonaosztást a köznép körében. ${ }^{111}$ Augustus propagandájában tehát központi szerepet töltött be a mezőgazdaság produktivitásának hangsúlyozása, hiszen uralmának stabilitása múlhatott ezen.

Az Ara Pacis központi alakja az értelmezések szerint Ceres, de másodlagos utalások Venusra és Tellusra is vannak. Ugyanakkor érdemes egy egyszerü, Augustus korában élő néző helyébe képzelnünk magunkat. Mivel új államberendezkedés vette kezdetét, aminek jelei láthatók voltak, akár ők maguk is úgy gondolhatták, hogy jobb korszak köszönt rájuk. Augustus megoldotta a problémáikat a polgárháborús helyzet feloldásával, és rendezte Róma gabonaellátását. A populus Romanus egyszerű tagja azonban nyilván erős identitással rendelkezik, aminek egyik fontos kifejeződése az aventinusi istenhármas és annak egyik legkiemelkedőbb tagja, Ceres. Ha azt látja, hogy a római állam legelső polgára ezzel az istenséggel ábrázoltatja a beköszönő békét, nem pedig a capitoliumi Minervával, akkor arra asszociálhat, hogy a princeps Ceres jóindulatából teremthetett rendet, és neki is hálálja meg azt. Biztosak lehetünk abban, hogy Augustus tisztában volt ezzel, és azt is tudta, hogy a maga oldalára kell állítania a legszélesebb népréteget, és saját személyét össze kell kötnie az istennővel. A populus megnyerése

106 A. Woodman: Velleius Paterculus: The Caesarian and Augustan Narrative. Cambridge 1983. 255 sk.

107 Simon L. Z.: Renovata renascitur. Aranykormítosz és politikai reprezentáció a bukolikus költészetben. In: Fikció és propaganda az ókorban. Válogatás a VIII. Magyar Ókortudományi Konferencia előadásaiból. Szerk. Mayer P. - Tar I. Szeged 2010. 168 sk.

108 Tac. ann. 2. 49.

109 Ceres Mater és Ops Augusta oltárának Augustus általi felszentelése: CIL II. 244, illetve CIL 240. Augustus és az eleusisi misztériumok: Suet. Aug. 93.

${ }^{110}$ Le Bonniec: i. m. (40. jegyz.) 378 sk.

111 Grüll T.: A Római Birodalom gazdasága. Budapest 2017. 29 sk. 
nem Venuson, Telluson, Paxon vagy egy felülmúlhatatlan, összegyúrt, szinkretizált és poliszemantikus istenségen keresztül működött, hanem Ceres személyén keresztül, aki ekkor már évszázadok óta a római plebeius, majd populus Romanus identitásának központi alakja volt. Ugyanakkor feltételezhetjük azt is, hogy ezen lépésekkel nemcsak saját személyét kívánta reprezentálni és hatalmát megerősíteni, hanem a populus Romanust közelebb akarta hozni a domus Augustához, és ez a két elem testesítette meg együtt a patriát. A személyével szembeni minden támadás így a patria elleni támadásnak felel meg, és a princepsszel szembenállókat hazafiatlansággal lehet vádolni. ${ }^{112}$

Az oltár akaratlanul is arra készteti szemlélőjét, hogy Augustus Városba történő visszatértét összekösse Proserpina visszatérésével a fenti világba. Proserpina visszatérése anyjához a vegetáció újjáéledését jelképezi. Már saját korában is többen összekapcsolták Augustus visszatérését az aranykor eljövetelével, jól példázzák ezt Horatius művei. ${ }^{113}$ Nemcsak az általunk vizsgált panel, hanem az egész oltár is végső soron $\mathrm{Au}$ gustus visszatértének, ezáltal a békének és az új aranykornak, nem utolsósorban pedig a termékenységnek az ünnepét hirdeti a római világban. ${ }^{114}$

\title{
SUMMARY
}

Ara Pacis Augustae is the most frequently studied work of art in the ancient Roman history of art. The uninitiated eye sees an exquisitely crafted, detailed, multitude of reliefs, a unique work of art, but history and different collaborative sciences can render an excellent imprint of Augustus era from these tiny details. Owing to the Ara Pacis' chiselled reliefs, it is an excellent source for political history, history of religion, and ideology. The aim of this study is to take sides in the question of who is the main figure of the panel by dint of the iconographic features and recent literature.

Keywords: Ara Pacis Augustae, Ceres, roman religion, Augustus, Tellus

\author{
MAGDUS TAMÁS \\ ELTE BTK Történelem Szak \\ tomimagdus@gmail.com
}

A cikk a Creative Commons Attribution 4.0 International License (https://creativecommons.org/ licenses/by/4.0) feltételei szerint publikált Open Access közlemény, melynek szellemében a cikk bármilyen médiumban szabadon felhasználható, megosztható és újraközölhető, feltéve, hogy az eredeti szerző és a közlés helye, illetve a CC License linkje és az esetlegesen végrehajtott módosítások feltüntetésre kerülnek. (SID_1)

${ }^{112}$ W. Eder: Augustus and the Power of Tradition. In: The Cambridge Companion to the Age of Augustus. Ed. K. Galinsky. Cambridge 2007. 32 sk.

113 Hegyi W.: i. m. (68. jegyz.) 41-51.

${ }^{114}$ Hegyi W. Gy.: Elefántcsontkapu és aranykor. Ókor 14 (2015) 36 sk. 